\title{
Will Management Emotion Affect the Maturity Structure of Corporate Debt?
}

\author{
Guo-tong $\mathrm{Wu}$ \\ Faculty of Management and Economics, Dalian University of Technology \\ NO.2 Linggong Road, Ganjingzi District, Dalian 116024, China
}

\begin{abstract}
Based on behavioral finance theory, this paper takes 22186 observation samples of China's Shanghai and shenzhen a-shares from 2007 to 2017 as research objects, try to measure the degree of over-optimistic of management by analyzing the tone of listed companies' annual reports, on this basis, the influence mechanism of over-optimistic of management on corporate debt financing decisions is investigated, and the heterogeneity is analyzed from the property right nature, financing constraints and economic policy uncertainty. The research results show that: First, the Python language analysis module is used to analyze the management intonation vocabulary in the annual report, and to build a linear model of the management intonation with the actual business operation and future prospects of the enterprise, take the residual error of the linear model as the proxy variable of over-optimistic of the management, this provides a reliable measurement method for the subsequent theoretical research on overoptimistic of management; Secondly, over-optimistic of the management will lead to larger scale of new debt financing and longer debt maturity structure, which is still true after controlling endogenous problems; Third, when property rights are non-state-owned enterprises, financing constraints are more serious and economic policy uncertainties are higher, excessive optimism of management has a more significant impact on corporate debt financing. From the perspective of behavioral finance, this paper examines the influence of over-optimistic of management on corporate debt financing decisions, enriches the relevant theoretical literature on the influencing factors of corporate debt financing, and has positive significance for comprehensively understanding the decisionmaking process of corporate debt financing.
\end{abstract}

Keywords: Over-optimistic ; Debt Financing; Debt Maturity Structure

DOI: $10.7176 /$ RJFA/10-16-15

Publication date: August $31^{\text {st }} 2019$

\section{Introduction}

Stemed from psychology, over-optimistic means overestimating the possibility of better future prospects and underestimating the possibility of worse. As a kind of character trait, excessive optimism is prevalent among managers and influences theirs decisions of enterprise operation. The excessively optimistic managers often have more optimistic view about future prospects of enterprises, which will have an impact on corporate financing decisions. From the perspective of management optimism, we examine the influence of over-optimistic of management on corporate debt financing decisions and further enrich the relevant theoretical literature about the impact of management traits on the decisions of enterprise operation. Taking a-shares listed companies in China's Shanghai and shenzhen as research objects, this paper try to measure the degree of over-optimistic of management by analyzing the tone of listed companies' annual reports. On this basis, the influence mechanism of over-optimistic of management on corporate debt financing decisions is investigated, which makes the paper have significant theoretical and practical value. Our results suggest that: over-optimistic of the management will lead to longer debt maturity structure, which is still true after controlling endogenous problems. In addition, when property rights are non-state-owned enterprises, financing constraints are more serious and economic policy uncertainties are higher, excessive optimism of management has a more significant impact on corporate debt financing.

The contributions of the paper on theoretical research can be followed. Based on behavioral finance theory, we examine the influence of irrational behaviors of management on enterprises' debt maturity structure and enrich the relevant theoretical literatures on the influencing factors of decisions on corporate debt financing. However lots of significant researches were conducted in academia, there are still many black boxes in the research of decisions on corporate debt financing to be revealed. From the perspective of the traits of management's behaviors, our results suggest that the excessively optimistic management prefer the debt financing with longer maturity. The conclusions in this paper not only have positive significance for theoretical and practical circles to understand the endogenous influence mechanism of decisions on corporate debt financing but also provide some ideas for regulation to prevent financial crisis.

\section{Literature review and hypotheses development}

\subsection{Literature review}

Upper echelon theory supports that the heterogeneity characteristics of management will influence their decisions on enterprise operation profoundly. There has been abundant literatures on studying the impact of management's 
irrational behaviors on business decisions, which achieved fruitful research results. The current researches about the influence of management optimism on business decisions focus mainly on investment decisions and information disclosure. Concretely, the first part is investment decision. Excessive optimism of management could not lead enterprises to overinvest (Bake and Wurgler, 2012). Furthermore, managers who are excessively optimistic tend to invest less on research and development (Michel, 2010). The second part is information disclosure. The optimistic anticipation of management will aggravate companies' earnings manipulation (Hribar and Yang, 2010).

The influence factors of enterprises' debt financing are complex badly, and academia primarily investigates the event from internal factors and external factors. Firstly, the internal factors. State-owned enterprises are easy to get loans through political resources grasped by them (Faccio et al. , 2006). In addition, the ability of corporate earning responds negatively to the scale of debt financing, consistent with Boyer (2014). According to the research of Hackbarth (2003), the risk inclination of management will raise enterprises' asset-liability ratio .So does overconfidence (Fan, 2011). Furthermore, Zhang et al. concluded that overconfident management incline to choose debt financing of short-term. Secondly, the external factors. The higher level of financial development in a region, the longer maturity of corporate debt financing(Gorodnichenko and Schnitzer, 2013). Moreover, the scale of corporate debt financing is smaller when the economy develops at a high level, consistent with DeBoskey and Gillett (2013).

\subsection{Theoretical analysis and research hypothesis}

With the development of behavioral finance and social psychology, the 'rational man' hypothesis proposed by traditional economics becomes doubtable, and current researches examine the decisions of management in aspect of irrational gradually. As the critical trait of irrationality, over-optimistic will have effects on managements' decisions on corporate operation. On the one hand, management will overestimate future investment income and underestimate not only future investment risks but the possibility of adverseness when they are excessively optimistic. Then, the investment impulsion of management will be stronger, and the scale of investment will exceed the need or the optimal. Meanwhile, managers who are excessively optimistic need long-term capital so badly to invest in order to avoid the stress of short debt service. Management incline to external financing if internal financing cannot meet the needs. Excessively optimistic managers prefer the large-scale and long-term debt financing to equity financing because they think the stock price of firm is underestimated frequently. On the other hand, excessively optimistic managers often overestimate their abilities. These managers consider they can both grasp the opportunities of investment accurately and estimate the return and risk of investment project better because they hold stronger professional abilities and richer investment experience. Excessively optimistic managers hold they can deal with problems better, even if facing the adverse factors. The raise of management's ability of risk tolerance and level of risk preference is the reason why management who are excessively optimistic incline to the large-scale and long-term debt financing.

Hypothesis 1: Over-optimistic of management will raise the proportion of firms' long-term debts .

\section{Research design}

\section{1 sample selection and data sources}

This paper takes a-share listed companies in Shanghai and Shenzhen stock exchanges from 2008 to 2018 as research objects, excludes ST companies, companies with missing data, financial industry companies and companies with abnormal financial data, and finally obtains the annual observation samples of 22186 companies. This paper uses web crawler technology to capture the annual reports of listed companies in Shanghai and Shenzhen. Other financial data and corporate governance data come from the CSMAR database.

\subsection{Variable definitions}

3.2.1 Explained Variable

Debt maturity structure(DMS) is defined in this paper as long-term debt/total debt. The higher the value becomes, the stronger the enterprise's ability to obtain long-term debt is. At the same time, in order to ensure the reliability of the research conclusion, this paper also adopts other measurement methods for reanalysis. For details, please refer to the robustness test section.

3.2.2 Explanatory Variables

Due to the difficulty of observation and definition of management optimism, there are few relevant research results in academia. Recently, the study of management tone in academia provides a new way to measure management optimism in this paper. Following Henry. (2013) and Leone (2015), we analyze the tone of management in the annual report to predict the degree of optimism ${ }^{13}$.Following Huang et al(2013), the extent of over-optimistic of management is the following: 
Optimistic $_{i t}=\frac{P O S_{i t}-N E G_{i t}}{P O S_{i t}+N E G_{i t}}$

Where Optimistic represents the extent of management optimism, POS is the number of occurrence of optimistic words in the company's annual reports, and $N E G$ is the number of occurrence of pessimistic words in the company's annual reports. The higher the value of Optimistic is , the higher the degree of management's optimism is.

Huang et al(2013) points out that the tone in management's annual reports is a reflection of the company's actual operations and future prospects. The management tone should have the linear relationship with the actual operation and future prospects of the enterprise as follows:

$$
\begin{aligned}
\text { Optimistic }_{i t}= & \alpha_{0}+\alpha_{1} \text { EPS }_{i t}+\alpha_{2} \Delta \text { EPS }_{i t}+\alpha_{3} \text { Size }_{i t}+\alpha_{4} \text { Lev }_{i t}+\alpha_{5} \text { Growth }_{i t} \\
& +\alpha_{6} \text { ROE }_{i t}+\alpha_{7} \text { Age }_{i t}+\alpha_{8} \text { LosS }_{i t}+\varepsilon
\end{aligned}
$$

Where EPS represents earnings per share, Size represents the size of the enterprise which equals the natural log of total assets, Lev is asset-liability ratio, Growth is revenue growth rate, ROE is return on net assets, Age represents the listing period and Loss represents weather it is defective dummy variable. Model (3) regression residuals represent the extent to which the optimistic tone of the management does not match the actual operation and future prospects of the enterprise, which can be used as a proxy variable for Over-Optimistic of the management. The higher the residual value, the higher the degree of over-optimistic of the management. Considering the differences in actual operation and future prospects of enterprises in different industries and in different years, this paper adopts the regression by year and industry to calculate the over-optimistic of the management, and then obtains the residuals of the regression model.

3.2.3 Control variable

Following Florou and Kosi(2015)、Rodano et al(2016)、Fuller et al(2018),we mainly select the following control variables: the size of the enterprise, profitability, growth ability, solvency, cash flow, age, asset liquidity, management efficiency, board size, independent director ratio, supervisory and ownership concentration.

\subsection{Model Specification}

This paper builds the following test model:

$$
\begin{aligned}
& D M S_{i t}=\chi_{0}+\chi_{1} \text { Over }- \text { Optimistic }_{i t}+\chi_{2} \text { Size }_{i t}+\chi_{3} \text { ROE }_{i t}+\chi_{4} \text { Growth }_{i t}+\chi_{5} \text { Lev }_{i t} \\
& +\chi_{6} \mathrm{CF}_{i t}+\chi_{7} \text { Age }_{i t}+\chi_{8} \text { Liquidity }_{i t}+\chi_{9} \text { Turnover }_{i t}+\chi_{10} \text { Dsize }_{i t}+\chi_{11} \text { Dir }_{i t} \\
& +\chi_{12} \text { Ssize }_{i t}+\chi_{13} \text { Top }_{i t}+\sum \text { Year }_{i t}+\sum \text { Ind }_{i t}+\varepsilon
\end{aligned}
$$

Among them, $D M S_{i t}$ is the debt maturity structure of company $i$ in year $t$. If the management is overly optimistic, the regression coefficient $\chi_{1}$ of Over-Optimisticit is significantly negative, which indicates that the more overly optimistic the management, the higher the proportion of long-term corporate debt; if the regression coefficient $\chi_{1}$ is significantly positive, it indicates that the more overly optimistic the management, the lower the proportion of long-term corporate debt.

\section{Empirical Results and Analysis}

\subsection{Descriptive statistics}

Table 1 shows the descriptive statistics of the main variables in this paper. The average debt maturity structure is 0.143 , which means that $14.3 \%$ of the total corporate debt is long-term debt. It can be seen that the financing of listed companies in China mainly relies on short-term debt and the debt maturity is short. The descriptive statistics of other variables are in line with the actual situation of the enterprise and will not be elaborated one by one. 
Table 1. Results of Descriptive Statistics of Variables

\begin{tabular}{ccccccccc}
\hline Variable & $N$ & Mean & SD & Min & $p 25$ & Median & $p 75$ & Max \\
\hline DMS & 22186 & 0.143 & 0.176 & 0.000 & 0.002 & 0.069 & 0.227 & 0.728 \\
Over-Optimistic & 22186 & -0.001 & 0.064 & -0.151 & -0.042 & -0.001 & 0.042 & 0.156 \\
Size & 22186 & 21.888 & 1.309 & 19.073 & 20.955 & 21.743 & 22.644 & 25.823 \\
ROE & 22186 & 0.066 & 0.140 & -0.729 & 0.030 & 0.071 & 0.117 & 0.527 \\
Growth & 22186 & 0.211 & 0.594 & -0.629 & -0.010 & 0.101 & 0.281 & 4.370 \\
Lev & 22186 & 0.448 & 0.225 & 0.047 & 0.270 & 0.440 & 0.612 & 1.098 \\
CF & 22186 & 0.041 & 0.077 & -0.206 & 0.001 & 0.041 & 0.086 & 0.262 \\
Age & 22186 & 2.015 & 0.902 & 0.000 & 1.386 & 2.302 & 2.772 & 3.178 \\
Liquidity & 22186 & 0.568 & 0.216 & 0.083 & 0.414 & 0.582 & 0.736 & 0.971 \\
Turnover & 22186 & 0.632 & 0.454 & 0.048 & 0.334 & 0.524 & 0.787 & 2.593 \\
Dsize & 22186 & 2.150 & 0.204 & 1.609 & 2.079 & 2.197 & 2.197 & 2.708 \\
Dir & 22186 & 0.371 & 0.053 & 0.273 & 0.333 & 0.333 & 0.400 & 0.571 \\
Ssize & 22186 & 1.262 & 0.258 & 1.099 & 1.099 & 1.099 & 1.609 & 1.946 \\
Top1 & 22186 & 0.354 & 0.153 & 0.087 & 0.233 & 0.335 & 0.461 & 0.758 \\
\hline
\end{tabular}

4.2 Univariate Analysis

This paper uses the $\mathrm{T}$ test and the Wilcoxon $\mathrm{Z}$ test to examine the differences in variables between sample groups of different degree of management over-optimism. Table 2 shows the results of the univariate analysis. Taking the debt maturity structure $(D M S)$ as an example, in the sample with high degree of management over-optimism, the average debt maturity structure is 0.147 , and in the sample with low degree of management over-optimism, the average debt maturity structure is 0.140 . It can be seen that the debt maturity structure of the high degree of overoptimistic management group is higher than the sample group, and both are significantly positive at the $1 \%$ level. The above analysis shows that the sample group with high degree of over-optimistic management has a higher proportion of long-term liabilities than the management group with low degree of optimism, which preliminarily confirms the research hypothesis of this paper.

Table 2. Results of the Univariate Analysis

\begin{tabular}{|c|c|c|c|c|c|c|}
\hline \multirow{2}{*}{ Variable } & \multicolumn{2}{|c|}{ High } & \multicolumn{2}{|c|}{ Low } & \multirow{2}{*}{ T test } & \multirow{2}{*}{ Wilcoxon Z } \\
\hline & Average & Median & Average & Median & & \\
\hline$D M S$ & 0.147 & 0.070 & 0.140 & 0.067 & $0.007 * * *$ & $0.003 * * *$ \\
\hline Size & 21.956 & 21.804 & 21.833 & 21.692 & $0.123 * * *$ & $0.112 * * *$ \\
\hline$R O E$ & 0.061 & 0.076 & 0.071 & 0.064 & $-0.009 * * *$ & $0.012 * * *$ \\
\hline Growth & 0.217 & 0.109 & 0.207 & 0.091 & 0.010 & $0.018 * * *$ \\
\hline Lev & 0.456 & 0.433 & 0.441 & 0.451 & $0.015 * * *$ & $0.018 * * *$ \\
\hline$C F$ & 0.039 & 0.043 & 0.043 & 0.039 & $-0.004 * * *$ & $0.004 * * *$ \\
\hline Age & 1.898 & 2.079 & 2.159 & 2.398 & $-0.261 * * *$ & $-0.319 * * *$ \\
\hline Liquidity & 0.555 & 0.569 & 0.578 & 0.593 & $-0.024 * * *$ & $-0.024 * * *$ \\
\hline Turnover & 0.644 & 0.524 & 0.622 & 0.524 & $0.022 * * *$ & 0.000 \\
\hline Dsize & 2.151 & 2.197 & 2.149 & 2.197 & 0.002 & 0.000 \\
\hline Dir & 0.371 & 0.333 & 0.371 & 0.333 & 0.000 & 0.000 \\
\hline Ssize & 1.270 & 1.099 & 1.255 & 1.099 & $0.015 * * *$ & $0.000 * * *$ \\
\hline Top1 & 0.354 & 0.336 & 0.355 & 0.333 & -0.001 & 0.003 \\
\hline
\end{tabular}

Note: $* \mathrm{p}<0.10, * * \mathrm{p}<0.05, * * * \mathrm{p}<0.01$

\subsection{Management over-optimistic and corporate debt maturity structure}

From the empirical test results in Table 3, it can be found that the regression coefficient of the corporate debt maturity structure is 0.113 , and it is highly significant at the $1 \%$ level, which indicates that a one standard deviation increase in the management's excessive optimism causes the increase in the proportion of long-term liabilities by 2.0. The percentage is equivalent to $13.99 \%$ of the sample mean. This positive promotion effect is significant both economically and statistically. In the regression results of the control variables in Table 3, the regression coefficients of the company's size (Size), profitability (ROE), growth ability (Growth), solvency (Lev), and operating efficiency (Turnover) are significantly positive, and the listing period (Age), asset liquidity (Liquidity), and board size (Dsize) are significantly negative. This means that enterprises with larger scale, higher profitability and growth ability obtain the greater the scale of debt financing and have the stronger ability to get long-term debt. The results are basically consistent with the conclusions of the current mainstream research literature on debt financing (Hadlock and Pierce, 2010 ; Fan et al., 2012), because debt financing has a lot of financial risks and only 
large-scale, cash-rich enterprises can repay their debts on time and avoid financial difficulties.

Table 3. Regression Results of Management Over-optimistic and Corporate Debt Maturity Structure

\begin{tabular}{|c|c|c|}
\hline Variable & $D M S_{i t}$ & $D M S_{i, t+1}$ \\
\hline Over-Optimistic ${ }_{i t}$ & $\begin{array}{c}0.113 * * * \\
(4.211)\end{array}$ & $\begin{array}{c}0.107 * * * \\
(3.723)\end{array}$ \\
\hline Size $_{i t}$ & $\begin{array}{c}0.040 * * * \\
(18.595)\end{array}$ & $\begin{array}{c}0.039 * * * \\
(17.045)\end{array}$ \\
\hline$R O E_{i t}$ & $\begin{array}{c}0.025 * * * \\
(2.817)\end{array}$ & $\begin{array}{c}0.052 * * * \\
(4.989)\end{array}$ \\
\hline Growth $_{i t}$ & $\begin{array}{c}0.006 * * * \\
(3.113)\end{array}$ & $\begin{array}{c}0.007 * * * \\
(3.233)\end{array}$ \\
\hline $\operatorname{Lev}_{i t}$ & $\begin{array}{c}0.093 * * * \\
(8.974)\end{array}$ & $\begin{array}{c}0.066^{* * *} \\
(5.989)\end{array}$ \\
\hline$A g e_{i t}$ & $\begin{array}{c}-0.123^{* * *} \\
(-6.602)\end{array}$ & $\begin{array}{c}-0.138 * * * \\
(-6.924)\end{array}$ \\
\hline Liquidity $_{i t}$ & $\begin{array}{c}-0.007 * * * \\
(-2.605)\end{array}$ & $\begin{array}{c}-0.007 * * \\
(-2.177)\end{array}$ \\
\hline Turnover $_{i t}$ & $\begin{array}{c}0.227 * * * \\
(18.702)\end{array}$ & $\begin{array}{c}0.215 * * * \\
(16.948)\end{array}$ \\
\hline$D_{\text {size }}{ }_{i t}$ & $\begin{array}{c}-0.073 * * * \\
(-14.690)\end{array}$ & $\begin{array}{c}-0.067 * * * \\
(-13.036)\end{array}$ \\
\hline$D i r_{i t}$ & $\begin{array}{c}-0.009 \\
(-0.732)\end{array}$ & $\begin{array}{c}-0.002 \\
(-0.175)\end{array}$ \\
\hline Ssize $_{i t}$ & $\begin{array}{c}-0.009 \\
(-0.251)\end{array}$ & $\begin{array}{c}0.008 \\
(0.215)\end{array}$ \\
\hline Top $1_{i t}$ & $\begin{array}{c}0.010 \\
(1.154)\end{array}$ & $\begin{array}{c}0.009 \\
(0.976)\end{array}$ \\
\hline Constant & $\begin{array}{c}-0.494 * * * \\
(-9.704)\end{array}$ & $\begin{array}{c}-0.678 * * * \\
(-14.458)\end{array}$ \\
\hline $\begin{array}{c}\text { Year/Ind } \\
\text { Adj- } R^{2}\end{array}$ & $\begin{array}{c}\text { Control } \\
0.388\end{array}$ & $\begin{array}{c}\text { Control } \\
0.358\end{array}$ \\
\hline$N$ & 22186 & 19170 \\
\hline
\end{tabular}

Note: ${ }^{*} p<0.10,{ }^{* *} p<0.05,^{* * *} p<0.01 ; t$ value in parentheses; standard errors are processed by double clustering at the corporate and annual levels

\subsection{Robustness Test}

4.4.1 Substituting the measuring method of Explanatory Variables

This paper uses two ways to re-measure the over-optimism of management: first, we recalculate Optimisticl by using Henry (2006), Price (2012) and so on, and then bring it into the model (2) to calculate Over-Optimisticl. The formula for calculating Optimisticl is shown in model (8). From the robustness test results in Table 4, we can see that there is a significant positive correlation between Over-Optimistic and DMS at the level of $1 \%$, and the research conclusion has not changed.

Secondly, design dumb variables of management over-optimism: Dummy. Change Optimistic into Dumb Variable. When Optimistic is greater than 0, Dummy is 1, otherwise Dummy is 0 . The regression results in Table 7 show that the regression coefficient of Over-Optimistic is significantly positive at the level of $1 \%$, which is consistent with the previous one.

4.4.2 Substituting the measuring method of Interpreted Variables

In this paper, we use long-term debt/total borrowing as the proxy variable of corporate debt maturity structure $\left(D F S 1_{i t}.\right)$. The regression results in Table 4 show that the regression coefficients of Over-Optimistic are significantly positive at the level of $1 \%$ and $5 \%$ respectively, which supports the conclusions of the previous study. 4.4.3 Reselect the samples

In this paper, we use the model (2) to calculate the degree of management over-optimism. Over-Optimistic is negative in 11250 annual observation samples and positive in 10936 annual observation samples. In this paper, the annual observation samples with negative Over-Optimistic number are deleted and the regression samples are 
reconstructed. The regression results in Table 4 show that the regression coefficients of Over-Optimistic are significantly positive at the level of $5 \%$, and the conclusions of the study have not changed substantially.

Table 4 Regression Results of Robustness Test

\begin{tabular}{|c|c|c|c|c|}
\hline \multirow{2}{*}{ Variable } & \multicolumn{2}{|c|}{ Replace Explanatory Variables } & \multirow{2}{*}{$\begin{array}{c}\text { Replace Interpreted Variables } \\
\qquad M S 1_{i t}\end{array}$} & \multirow{2}{*}{$\begin{array}{c}\text { Reselect the Samples } \\
D M S_{i t} \\
\end{array}$} \\
\hline & $D M S_{i t}$ & $D M S_{i t}$ & & \\
\hline Over-Optimistic $1_{i t}$ & $\begin{array}{c}0.187 * * * \\
(4.209)\end{array}$ & & & \\
\hline Dummy $_{i t}$ & & $\begin{array}{c}0.012 * * * \\
(3.978)\end{array}$ & & \\
\hline Over-Optimistic ${ }_{i t}$ & & & $\begin{array}{c}0.064 * * \\
(2.296)\end{array}$ & $\begin{array}{c}0.008 * * \\
(2.178)\end{array}$ \\
\hline Size $_{i t}$ & $\begin{array}{c}0.039 * * * \\
(18.448)\end{array}$ & $\begin{array}{c}0.039 * * * \\
(19.285)\end{array}$ & $\begin{array}{c}0.064 * * * \\
(16.761)\end{array}$ & $\begin{array}{c}0.036 * * * \\
(13.117)\end{array}$ \\
\hline$R O E_{i t}$ & $\begin{array}{c}0.027 * * * \\
(2.964)\end{array}$ & $\begin{array}{c}0.027 * * * \\
(3.152)\end{array}$ & $\begin{array}{c}0.074 * * * \\
(4.555)\end{array}$ & $\begin{array}{c}0.048 * * * \\
(3.850)\end{array}$ \\
\hline Growth $_{i t}$ & $\begin{array}{c}0.006 * * * \\
(3.220)\end{array}$ & $\begin{array}{c}0.005 * * * \\
(3.207)\end{array}$ & $\begin{array}{c}0.014 * * * \\
(4.230)\end{array}$ & $\begin{array}{c}0.004 \\
(1.345)\end{array}$ \\
\hline $\operatorname{Lev}_{i t}$ & $\begin{array}{c}0.094 * * * \\
(9.119)\end{array}$ & $\begin{array}{c}0.089 * * * \\
(9.247)\end{array}$ & $\begin{array}{c}0.145 * * * \\
(7.555)\end{array}$ & $\begin{array}{c}0.098 * * * \\
(7.292)\end{array}$ \\
\hline$A g e_{i t}$ & $\begin{array}{c}-0.123 * * * \\
(-6.588)\end{array}$ & $\begin{array}{c}-0.107 * * * \\
(-6.147)\end{array}$ & $\begin{array}{c}0.022 \\
(0.643)\end{array}$ & $\begin{array}{c}-0.151 * * * \\
(-5.958)\end{array}$ \\
\hline Liquidity $_{i t}$ & $\begin{array}{c}-0.007 * * * \\
(-2.664)\end{array}$ & $\begin{array}{c}-0.010 * * * \\
(-4.445)\end{array}$ & $\begin{array}{c}0.009^{*} \\
(1.689)\end{array}$ & $\begin{array}{l}-0.006^{*} \\
(-1.689)\end{array}$ \\
\hline Turnover $_{i t}$ & $\begin{array}{c}0.227 * * * \\
(18.705)\end{array}$ & $\begin{array}{c}0.220 * * * \\
(19.164)\end{array}$ & $\begin{array}{c}0.202 * * * \\
(9.591)\end{array}$ & $\begin{array}{c}0.236 * * * \\
(15.351)\end{array}$ \\
\hline Dsize $_{i t}$ & $\begin{array}{c}-0.074 * * * \\
(-14.713)\end{array}$ & $\begin{array}{c}-0.073 * * * \\
(-15.805)\end{array}$ & $\begin{array}{c}-0.109 * * * \\
(-13.291)\end{array}$ & $\begin{array}{c}-0.077 * * * \\
(-11.191)\end{array}$ \\
\hline $\operatorname{Dir}_{i t}$ & $\begin{array}{c}-0.008 \\
(-0.718)\end{array}$ & $\begin{array}{l}-0.003 \\
(-0.286)\end{array}$ & $\begin{array}{c}-0.009 \\
(-0.431)\end{array}$ & $\begin{array}{c}0.005 \\
(0.330)\end{array}$ \\
\hline Ssize $_{i t}$ & $\begin{array}{c}-0.009 \\
(-0.244)\end{array}$ & $\begin{array}{c}0.005 \\
(0.136)\end{array}$ & $\begin{array}{c}0.005 \\
(0.068)\end{array}$ & $\begin{array}{c}0.069 \\
(1.428)\end{array}$ \\
\hline Top $_{i t}$ & $\begin{array}{c}0.010 \\
(1.148)\end{array}$ & $\begin{array}{c}0.012 \\
(1.443)\end{array}$ & $\begin{array}{c}0.016 \\
(1.022)\end{array}$ & $\begin{array}{c}0.013 \\
(1.193)\end{array}$ \\
\hline Constant & $\begin{array}{c}-0.487 * * * \\
(-9.583) \\
\end{array}$ & $\begin{array}{l}-0.729 * * * \\
(-17.407)\end{array}$ & $\begin{array}{c}-0.933 * * * \\
(-9.324) \\
\end{array}$ & $\begin{array}{l}-0.611 * * * \\
(-10.137)\end{array}$ \\
\hline $\begin{array}{c}\text { Year/Ind } \\
\text { Adj- } R^{2} \\
N\end{array}$ & $\begin{array}{c}\text { Control } \\
0.387 \\
22186\end{array}$ & $\begin{array}{c}\text { Control } \\
0.379 \\
22186\end{array}$ & $\begin{array}{c}\text { Control } \\
0.309 \\
22186\end{array}$ & $\begin{array}{c}\text { Control } \\
0.384 \\
10936\end{array}$ \\
\hline
\end{tabular}

Note: $* \mathrm{p}<0.10, * * \mathrm{p}<0.05, * * * \mathrm{p}<0.01 ; t^{-}$value in parentheses; standard error is processed by double clustering at company and annual level.

\section{Research Conclusion}

The existing literature on corporate debt financing is mostly from the corporate characteristics and corporate governance level to find the influencing factors, few literature from the perspective of behavioral finance to explore corporate debt financing. Behavioral finance theory has been widely used in corporate finance. This paper examines the influencing factors of corporate debt financing from the perspective of excessive optimism of management. The study finds that the debt maturity structure of enterprises with excessive optimism of management is longer, and the above conclusion is still valid after controlling the endogenous problem.

\section{References}

Baker M P, Wurgler J. Behavioral Corporate Finance: An Updated Survey[R]. Working Paper, 2011.

Boyer M . Directors' and Officers' Insurance and Shareholder Protection[J]. Journal of Financial Perspectives, 2014, 2(3):107-128.

DeBoskey D G, Gillett P R. The Impact of Multi-dimensional Corporate Transparency on us Firm' Credit Ratings and Cost of Capital[J]. Review of Quantitative Finance and Accounting, 2013, 40(1), 101-134.

Faccio M, Masulis R W, McConnell J J. Political Connections and Corporate Bailouts[J]. The Journal of Finance, 2006, 61(6): 2597-2635.

Fan J P H , Titman S, Twite G . An International Comparison of Capital Structure and Debt Maturity Choices[J]. Journal of Financial and Quantitative Analysis, 2012, 47(01):23-56. 
Fan T. Managerial Risk Incentives and the Covenant Structure of Debt[R].Working paper, 2010.

Florou A, Kosi U. Does Mandatory IFRS Adoption Facilitate Debt Financing?[J]. Review of Accounting Studies, 2015, 20(4): 1407-1456.

Fuller K P, Yildiz S, Uymaz Y. Credit Default Swaps and Firms' Financing Policies[J]. Journal of Corporate Finance, 2018, 48: 34-48.

Gorodnichenke Y, Schnizer M. Financial Constraints and Innovation: Why Poor Countries Don't Catch Up [J]. Journal of the European Economic Association, 2013,11(5):1115-1152.

Hackbarth D. Managerial Traits and Capital Structure Decisions[J]. Journal of Financial \& Quantitative Analysis, 2003, 43(4):843 881

Hadlock C J , Pierce J R. New Evidence on Measuring Financial Constraints: Moving Beyond the KZ Index[J]. Review of Financial Studies, 2010, 23(5):1909-1940.

Heaton J B. Managerial Optimism and Corporate Finance[J]. Financial Management, 2002, 31(2):33 45.

Henry E, Leone A J. Measuring Qualitative Information in Capital Markets Research: Comparison of Alternative Methodologies to Measure Disclosure Tone[J]. The Accounting Review, 2015, 91(1): 153-178.

Hribar P, Yang H. Does CEO Overconfidence Affect Management Forecasting and Subsequent Earnings Management[R]. Working Paper, 2010.

Huang X, Teoh S H, Zhang Y. Tone Management[J]. The Accounting Review, 2013, 89(3): 1083-1113.

Michel J S. Does Managerial Optimism Lead to Long-Run Underperformance? Evidence from Venture CapitalBacked IPOs[R]. Working Paper, 2010.

Rodano G, Serrano-Velarde N, Tarantino E. Bankruptcy Law and Bank Financing[J]. Journal of Financial Economics, 2016, 120(2): 363-382.

Zhang M, Lijun M, Zhang B, Yi Z. Pyramidal Structure, Political Intervention and Firms' Tax Burden: Evidence from China's Local SOEs[J]. Journal of Corporate Finance, 2016, 36:15-25. 